JPDN ISSN 2579-6461 (Online) ISSN 2460-6324 (Print)

Jurnal Pendidikan Dasar Nusantara

Volume 6| Nomor 1| Juli 2020|

DOI: https://doi.org/10.29407/jpdn.v6i1.14555

\title{
Pengaruh Kegiatan Robotika Terhadap Keterampilan Berpikir Kreatif Siswa Usia SD
}

\author{
Rossy Miselina ${ }^{1}$, Abdul Muhid ${ }^{2}$ \\ rossy_s2@untag-sby.ac.id ${ }^{1}$, abdulmuhid@uinsby.ac.id ${ }^{2}$ \\ Psikologi, Mahasiswa Magister Psikologi, Universitas 17 Agustus 1945 ${ }^{1}$ \\ Psikologi, Dosen Psikologi, UIN Sunan Ampel Surabaya ${ }^{2}$ \\ No Handphone +628127074526, +6282139113730
}

\begin{abstract}
Abstrak: Keterampilan berpikir menjadi salah satu aspek penting dalam menciptakan ide, konsep, dan kreativitas untuk membuat sesuatu hasil karya yang baru. Keterampilan berpikir sangat diperlukan bagi siswa usia SD karena menyangkut instrumen pengembangan dalam diri untuk dapat memperoleh pengetahuan sekaligus wawasan dalam membentuk kreativitas. Kegiatan robotika memiliki keterkaitan dengan keterampilan berpikir secara kreatif, karena kegiatan ini tidak hanya dilakukan sebagai kegiatan untuk mengembangkan suatu ide, konsep, dan karya tetapi menjadi salah satu keterampilan dalam berpikir siswa untuk dapat mengeskplorasi kemampuan dalam dirinya sehingga siswa dapat melatih dan meningkatkan kemampuan motoriknya dalam menciptakan ide, konsep, dan karya dalam kegiatan robotika.
\end{abstract}

Kata Kunci: Keterampilan Berpikir, Robotika, Kreativitas, Pengembangan Diri

\section{Influence Robotics Activity To Creative Thinking Skills for Elementary School Students}

\begin{abstract}
Thinking skills become one of the important aspects in creating ideas, concepts, and creativity to make something new work. Thinking skills are very necessary for elementary school students because it involves instruments of development in themselves to be able to gain knowledge as well as insight in shaping creativity. Robotics activities are related to creative thinking skills, because this activity is not only done as an activity to develop ideas, concepts, and works but is one of the skills in thinking students to be able to explore their abilities so that students can train and improve their motor skills in creating ideas, concepts, and works in robotics activities.
\end{abstract}

Keyword $s$ : Thinking Skills, Robotics, Creativity, Personal Development

\section{PENDAHULUAN}

Pendidikan menjadi dasar dalam membangun dan mengembangkan kreativitas dalam diri untuk dapat berkembang dan maju. Pendidikan memiliki tujuan tidak hanya sebagai 
pedoman bagi setiap individu. Tetapi dapat menjadikan acuan dalam komponen mengembangkan potensi yang dimiliki dalam diri. Pendidikan tidak hanya dapat dilakukan disekolah secara formal, tetapi pendidikan dapat dilakukan diluar sekolah atau secara nonformal untuk dapat memperluas jangkauan dalam mengembangkan diri. Pendidikan nonformal seperti lembaga pelatihan, kursus, dan kegiatan pembelajaran dapat mengembangkan kemampuan dan keterampilan bagi setiap individu (UU No. 20 Tahun 2003). Pendidikan ini dapat meningkatkan keterampilan, pengetahuan, wawasan, dan kreativitas dalam melakukan setiap aktivitasnya.

Menurut Undang-undang No. 20 Tahun 2003 Tentang Sistem Pendidikan Nasional dalam Pasal 17 dan 28 menjelaskan bahwa pendidikan Sekolah Dasar (SD) menjadi pendidikan dasar dalam setiap siswa dalam mengembangkan potensi diri sehingga pendidikan menentukan keterampilan dan kreativitas dalam diri. Pendidikan tidak hanya dapat dilakukan secara formal tetapi pendidikan

nonformal dan informal menjadi pembelajaran dasar dalam membentuk karakter siswa tersebut. Pendidikan sangat menentukan kualitas siswa dalam mendapatkan kreativitas dan keterampilan, karena pengembangan ini dapat membawa efek terhadap intelektual dan kepribadian siswa tersebut (Kemendikbud, 2014). Salah satu kegiatan nonformal yang dapat mengembangkan keterampilan berpikir siswa yakni kegiatan robotika. Kecanggihan teknologi menjadi salah satu instrumen utama negara dalam memajukan negaranya sehingga penggunaan teknologi robotika menjadi instrumen utama negara-negara maju dalam memajukan negaranya (Endra, 2006: 1). Teknologi robotika merupakan penggunaan teknologi dalam penerapannya yang menggunakan teknik elektro, teknik mesin, teknik industri, ilmu komputer dan matematika sehingga implementasi robotika ini menggunakan keterampilan dan kreativitas dalam kegiatannya (Hotman, 2012: 2). Jika dilihat dari implementasi tersebut dapat mengembangkan keterampilan dalam menggunakan berbagai teknologi canggih.

Kegiatan robotika menjadi salah satu kegiatan yang memiliki pengaruh terhadap kemampuan berpikir siswa. Karena siswa tidak hanya dituntut untuk dapat membuat ide dan konsep dalam robotika, tetapi dituntut untuk dapat berpikir secara divergen (menyebar dan tidak searah) untuk mengembangkan keterampilan berpikir dan kreativitas (Nashroni \& Diana, 2002). Di Indonesia, lembaga pendidikan dan orang tua cenderung mengarahkan dan mendidik siswa secara konvergen (terpusat dan searah) sehingga siswa cenderung memiliki satu jalan saja dalam mencari jalan keluar dalam setiap permasalahan. Kegiatan robotika menjadi kegiatan yang mampu mendorong siswa terutama siswa SD dalam mengembangkan diri untuk 
berpikir secara bebas dalam memecahkan suatu permasalahan sehingga siswa dapat memiliki kemampuan keterampilan berpikir secara dinamis.

Keterampilan berpikir secara sistematis memiliki implikasi adanya eskalasi kemajuan dalam kemampuan berpikir sehingga hal ini akan terjadi suksesi, diskontinuitas, diferensiasi, dan integrasi dalam perkembangannya (Yeni, 2010: 13). Jika siswa SD sejak dini telah diajarkan berpikir secara sistematis. Maka mereka dapat merepresentasikan dan kemampuan dalam bidang yang mereka kerjakan sehingga keterampilan berpikir mereka akan berkembang dan tumbuh dengan sendirinya. Hal ini seperti dalam kegiatan robotik, siswa SD diharapkan mampu untuk merancang ide, konsep, dan produk sehingga mereka dapat menggunakan keterampilan berpikir mereka untuk dapat mengambangkan minat dan kemampuan mereka. Menurut Hotman (2012) keterampilan dalam berpikir secara kreatif umumnya diajarkan oleh keluarga. Sikap dan perilaku orang tua memiliki pengaruh terhadap keterampilan berpikir bagi anak/ siswa tersebut. Akibat terdapat beberapa sikap dan perilaku yang tidak sesuai sehingga hal ini akan menghambat keterampilan berpikir dan kreativitas anak dalam melakukan aktivitasnya. Pendidikan yang tidak sesuai juga dapat memiliki pengaruh terhadap ide, keterampilan, dan kreativitas siswa dalam melakukan kegiatannya sehingga kegiatan robotika yang dilakukan pada masa usia SD diharapkan mampu memberikan siswa kesempatan dalam melakukan eksplorasi secara kreatif, aktif dalam mendorong kemampuan berpikir bagi siswa usia SD (Ario, 2012: 31). Berdasarkan permasalahan yang terjadi, penyebab siswa tidak memiliki kemampuan dalam keterampilan berpikir secara sistematis yaitu siswa tidak dituntut untuk dapat berkembang secara divergen sehingga siswa tidak mengembangkan keterampilan, pengetahuan dan kreativitasnya dalam lingkungan sekitar dalam kemampuan berpikir kreatif berdasarkan kajian literatur.

\section{Rumusan Masalah}

Berdasarkan permasalahan di atas, maka penulis akan mengkaji

1. Bagaimana creative thinking skill dapat mempengaruhi siswa dalam kegiatan robotika?

\section{Tujuan}

Tujuan dalam penelitian ini diharapkan mampu menjelaskan pengaruh kegiatan robotika terhadap kemampuan berpikir kreatif siswa usia SD berdasarkan kajian literatur. Dengan demikian, kegiatan robotika yang dilakukan tidak hanya dapat menumbuhkembangkan potensi dalam diri siswa tersebut, tetapi siswa dituntut mampu memiliki kemampuan berpikir kreatif secara dinamis untuk masa depannya. 


\section{PEMBAHASAN}

\section{DEFINISI KREATIVITAS}

Kreativitas menjadi salah satu aspek yang ada didalam setiap individu yang dapat dilakukan secara spontanitas (Robert, 2007: 437). Kreativitas dapat dimiliki oleh setiap individu sehingga mereka mampu menggambarkan pola pikir yang kreatif dan mampu mengabstraksikan imajinasinya (Amal, 2005: 29). Kreativitas menjadi kemampuan dalam menghasilkan ide, dan konsep untuk dapat memecahkan masalah sehingga mereka mampu melakukan eloborasi dalam mewujudkan ide menjadi kenyataan (Indira, 2013: 12). Dengan demikian, kreativitas tidak hanya mampu mengabstraksikan dan mewujudkan ide menjadi kenyataan, tetapi mereka diharapkan mampu untuk memecahkan permasalahan yang dihadapi guna mengasah kemampuan berpikir secara kreatifnya. Dalam mengabstraksikan ide dan imajinasinya mereka memiliki kemampuan berpikir dalam menggambarkan pola imajinasi yang akan mereka terapkan kedalam wujud nyata.

Sensitivity menjadi salah satu kepekaan dalam menangkap dan menghasilkan suatu hal berdasarkan situasi dan kondisi disekitarnya sehingga kreativitas memiliki hubungan dengan kreativitas dalam melakukan aktivitasnya (Yeni, 2012: 14). Kreativitas dilakukan atas dasar kesadaran individu dalam kemampuan dalam kecakapan sehingga berkaitan dengan bakat (Indira, 2013: 46). Kemampuan dalam kecakapan ini akan menciptakan sesuatu hal yang baru untuk dapat diterapkan dalam memecahkan permasalahan sehingga ini dapat dihubungkan dengan kemampuan berpikir seseorang secara kreatif. Kreativitas menjadi titik temu bahwa kepribadian dan motivasi seseorang akan berpengaruh terhadap cara berpikir kreatif (Utami, 2012: 20). Kemampuan dalam menciptakan suatu ide atau konsep dalam kreativitas ditentukan dari motivasi yang mereka dapatkan sehingga mereka berpikir untuk dapat menciptakan sesuatu hal yang baru berdasarkan kemampuan berpikir kreatif mereka.

Kreativitas memiliki berbagai tingkatan dalam mencapai puncaknya sehingga kreativitas memiliki definisi yang sangat luas (Utami, 2012: 21). Kreativitas dibagi menjadi beberapa bagian di antaranya adalah 1. Kreativitas ekspresionis, 2. Kreativitas produktif, 3. Kreativitas inovatif, 4. Kreativitas pembaruan, 5. Kreativitas emanasi. Kreativitas ini memiliki karakteristik dalam berpikir secara kreatif sehingga akan mempengaruhi kreativitasnya dalam berpikir, mengungkapkan gagasan/ ide, memecahkan permasalahan, dan melihat berbagai sudut pandang (Ahmad, 2011: 117). Sehingga diharapkan siswa mampu untuk meningkatkan berbagai indikator dalam menumbuhkan dan meningkatkan kemampuan berpikir secara kreatifnya dalam kehidupan sehari-hari (Yuliani, 2010: 40). Dengan demikian, bahwa kreativitas menjadi salah satu indikator dalam menumbuhkan kemampuan berpikir bagi 
seseorang yang berpengaruh terhadap kehidupan sehari-hari dalam melakukan aktivitasnya. Kreativitas memiliki berbagai bentuk sehingga kemampuan ini menjadi karakteristik bahwa kreativitas memiliki cakupan yang luas.

\section{KEGIATAN ROBOTIKA}

Kegiatan robotika yang dilakukan merujuk kepada bidang ilmu pengetahuan dan teknologi yang dikembangkan dan dioperasikan dengan robot dan sistem robot (Winarno \& Deni, 2011: 2). Pengimplementasian dalam robotika ini memerlukan keterampilan dalam merancang dan menerapkan robot dalam ide dan kegiatannya sehingga hal ini dapat menumbuhkan dan mengembangkan keterampilan berpikir bagi siswa (Hotman, 2012: 2). Kegiatan dan peran robotika saat ini memiliki pengaruh terhadap kehidupan, karena memiliki banyak manfaat yang diberikan dari penggunaan robotika ini. Menurut Ann-Marie, Michael Robinson dan Eric Wang (2007), menyebutkan bahwa :

"Robotic program will provide students an opportunity to explore robotics concepts in a creative, social environment that fosters learning, while providing further training for teachers".

Program robotika memiliki manfaat bagi siswa untuk dapat mengeksplorasi konsep robotika kedalam lingkungan sehari-harinya sehingga siswa dapat belajar lebih cepat dalam menyesuaikan pembelajaran dalam yang dilakukan. Pentingnya kegiatan robotika bagi siswa SD dipengaruhi oleh perkembangan zaman dan teknologi yang sudah semakin maju sehingga pengembangan teknologi robotika ini memiliki kontribusi yang besar bagi negara (Endra, 2006). Teknologi robotika ini memiliki peran besar dalam memajukan suatu negara, karena memiliki penggunaan dalam kecanggihan teknologi sehingga siswa memiliki peran dalam merakit dan merancang teknologi ini secara kreatif (Hotman, 2012). Meski demikian, dalam meningkatkan kreativitas siswa mereka akan memahami ide, imajinasi dengan menggunakan kreativitasnya dalam memecahkan permasalahan (Asrori, 2011: 61). Dengan demikian, kegiatan robotika ini selain untuk meningkatkan keterampilan bagi siswa, kegiatan robotika diharapkan mampu dalam mengikuti perkembangan zaman yang semakin canggih sehingga penerapan kegiatan robotika dapat memajukan negara dalam penggunaan teknologi canggih.

\section{METODE KEGIATAN ROBOTIKA BAGI SISWA USIA SD}

Pada era globalisasi ini siswa dituntut untuk dapat menyesuaikan dengan perkembangan zaman yang ada. Salah satu kegiatan yang berkembang sesuai dengan perkembangan zaman yaitu robotika yang tidak terlepas dari penggunaan teknologi canggih. 
Kegiatan robotika ini menjadi salah satu wadah bagi siswa dalam mengembangkan, mengimplementasikan, dan menyalurkan ide, pemikiran, gagasan, dan kreativitas mereka dalam bentuk suatu karya (Ario, 2012). Kegiatan robotika tidak hanya sebagai kegiatan pembelajaran bagi siswa tetapi memiliki manfaat dalam pengembangan siswa yang tidak hanya meningkatkan keterampilan berimajinasi, tetapi dapat merangsang kemampuan motorik siswa untuk dapat melatih kerjasama agar dapat berani mengekspresikan ide mereka dalam kegiatan sehari-hari (Ani, 2019). Kegiatan ini memiliki pengaruh dalam perkembangan siswa untuk menciptakan suatu karya sehingga siswa memiliki daya saing dalam menciptakan sebuah produk berdasarkan ide, konsep, dan imajinasi mereka (Harry, 2016). Kreativitas ini didapatkan tidak hanya dalam pembelajaran dikelas, tetapi kegiatan seperti robotika ini memiliki pengaruh dalam meningkatkan keterampilan berpikir secara kreatif sehingga siswa dapat memberikan prestasi dalam bidang robotika ini. Hal ini akan mempengaruhi perkembangan kreativitas bagi siswa dalam mengembangkan bakatnya sehingga siswa dapat menemukan hingga memecahkan masalah yang terjadi.

Menurut Ulfa (2018), pentingnya kegiatan robotika ini menjadi salah satu agenda penting dalam mengikuti perkembangan IT agar siswa tidak ketinggalan dalam teknologi dan informasi. Kegiatan robotika baik dalam ekstrakurikuler maupun kegiatan lainnya dapat mengais ilmu dalam bidang IT melalui robotika sehingga siswa dituntut untuk dapat kreatif dan inovatif dalam mengikuti perkembangan secara global. Robotika tidak hanya mengabstraksikan, melakukan penalaran dalam membuat karyanya. Tetapi robotika dalam Sutan (2012) memiliki hubungan dengan penalaran, kreativitas, imajinasi, pemecahan masalah, pemahaman konsep, dan pembentukan ide dalam melakukan kegiatannya sehingga kegiatan ini memiliki peran yang penting dalam keterampilan siswa dalam mengembangkan dirinya untuk dapat berpikir, merasakan, menginderakan dan intuisi (Kasmadi, 2012: 158). Sehingga dalam kegiatan robotika ini selain mengikuti perkembangan teknologi, kegiatan robotika ini bertujuan untuk dapat mengembangkan keterampilan siswa dalam melakukan pengembangan diri dalam kreativitasnya.

Tujuan utama dalam kegiatan robotika ini tidak terlepas dari mengembangkan keterampilan berpikir secara kreatif bagi siswa sehingga siswa dapat menggambarkan, membayangkan, hingga merakit dan memasang robotika ini (Ulfa, 2018: 71). Dengan melalui kegiatan ini siswa dapat meningkatkan kinerja otak kanan dalam melakukan pekerjaannya sehingga mereka menjadi lebih kreatif. Kreativitas siswa berada didalam dirinya sendiri melalui kegiatan ini siswa dituntut untuk dapat mengembangkan potensi yang ada didalam diri mereka (Yeni, 2010). Tidak hanya kreativitas saja yang berpengaruh dalam kegiatan ini tetapi 
pengembangan diri seperti kemampuan mengekspresikan diri, kepercayaan diri, dan kemampuan memecahkan permasalahan menjadi pengaruh besar dalam kegiatan ini (Ahmad, 2013: 102).

\section{HASIL DAN PEMBAHASAN PENGARUH THINKING SKILL DALAM KEGIATAN ROBOTIKA}

Salah satu kajian literatur dalam kegiatan robotika bagi siswa usia SD ini dilakukan oleh Ika Widiastuti et al., (2016) di SD Negeri Karangrejo 2 melalui ekstrakurikuler robotika. Kegiatan robotika ini merupakan salah satu program dari sekolah yakni ekstrakurikuler sebagai pelajaran tambahan bagi siswa untuk dapat menambah pengalaman dan pengetahuan dalam mengembangkan kemampuan berpikir secara kreatif (Baradista et all., 2016). Kegiatan ekstrakurikuler ini menjadi salah satu kegiatan yang banyak digemari mulai dari tingkat TK sampai SMA (Ika et al., 2016:323). Kegiatan robotika yang dilakukan oleh siswa usia SD memiliki maksud untuk memberikan pengenalan terhadap teknologi yang inovatif sehingga dapat memberikan dampak bagi Thinking Skill bagi siswa. Hal ini juga akan turut mengembangkan logika dan imajiasi bagi siswa untuk dapat merancang sebuah robot berdasarkan pemahaman ide, konsep yang mereka miliki. Kegiatan robotika di SD Negeri Karangrejo 2 ini memiliki tujuan tidak hanya memberikan pembelajaran mengenai robotika dan apa itu robotika, operasional robotika dan penggunaannya. Tetapi kegiatan ini sebagi salah satu contoh bagi sekolah-sekolah lain agar mengetahui bahwa kegiatan robotika tidak harus mengeluarkan biaya yang banyak. Pembelajaran ini dapat dilakukan secara sederhana tetapi tidak menyampingkan tujuan utama untuk dapat mengembangkan Thinking Skill dalam pengembangan teknologi dan siswa tidak tertinggal dalam kemajuan teknologi.

Pembelajaran yang dilakukan dalam kegiatan robotika ini disesuaikan dengan kapabilitas usia SD. Menurut Robert (1994) Kegiatan robotika ini secara sistematika dibuat dengan menggunakan sensor pendeteksi agar sebuah robot dapat mengikuti arah garis/ robot line follower sehingga siswa SD dalam kegiatan ini mampu memahami ide dan konsep pembuatan sistem robot dan mampu mengoperasikan dan mengetahui pembuatan robotika tersebut. Kegiatan robotika yang dilakukan di SD Negeri Karangrejo 2 memiliki berbagai kegiatan seperti pengenalan komponen elektronika, pengenalan robotika dan bagian-bagian robot, perakitan robot line follower hingga lomba mini robot line follower (Ika et al., 2016: 323). Siswa SD tidak hanya dituntut untuk dapat mengetahui, dan membuat robot tersebut, tetapi siswa turut berpartisipasi dalam lomba mini membuat robot tersebut sehingga siswa dapat mengembangkan Thinking Skill secara kreatif untuk membuat sebuah ide berupa robotika 
untuk mengasah kemampuan dalam dirinya. Dalam kegiatan robotika ini siswa SD dapat mempelajari, mengimplementasikan dan membuat robotika meskipun dalam pendampingan tenaga pengajar. Berdasarkan hal ini bahwa kegiatan robotika dapat meningkatkan kemampuan Thinking Skill siswa dalam bidang robotika berdasarkan pembuatan robot line follower (Pitowarno, 2006). Siswa diajarkan untuk dapat mengembangkan robot line follower dengan menentukan model robot, jalur robot sehingga siswa diajarkan untuk memiliki kemampuan berpikir secara kreatif agar dapat menghasilkan robot yang sesuai dengan kemampuan mereka.

Pengembangan robot line follower menjadikan siswa meningkatkan kreativitas yang lebih dalam pembuatan robotika tersebut dan siswa juga dalam membuat dan mencoba robot akan terus melakukan inovasi dan terus mencoba sehingga siswa dapat meningkatkan keterampilan berpikir untuk lebih kreatif untuk membuat suatu inovasi baru (Aceng et all., 2019: 10). Tidak hanya itu, siswa juga memiliki jiwa dalam memecahkan masalah dalam pembuatan robot ini sehingga siswa tidak hanya dituntut untuk dapat kreatif tetapi dituntut untuk dapat memecahkan permasalahan yang dihadapi (Aceng et all., 2019). Hal ini menjadi pengaruh yang penting bagi siswa untuk dapat membuat karya berdasarkan Thinking Skill agar dalam pembuatan dan perakitan robotika ini siswa memiliki pemahaman, wawasan dan pengetahuan dalam mendorong pembinaan sikap dan nilai dalam melatih kemampuan Thinking Skill bagi siswa tersebut (Baradista et all., 2016: 34).

Kegiatan robotika tidak hanya sebagai kegiatan untuk membuat sebuah karya, tetapi siswa SD dapat melakukan kegiatan ini sambil bermain sehingga dalam mengoperasikan, dan merakit robot ini akan terasa mengasikan dan tidak terasa lelah (Ani, 2019: 75). Melalui kegiatan ini siswa SD tidak akan merasa lelah, karena siswa diajarkan untuk membuat sebuah karya berdasarkan ide, dan kreativitas mereka dalam membuat robotika ini (Ika et al., 2016). Meskipun siswa menjadi aktor utama dalam kegiatan ini, tetapi peran tenaga pengajar memiliki peran penting dalam mengarahkan dan memotivasi siswa untuk dapat terus meningkatkan kreativitas mereka sehingga siswa memiliki pengetahuan dan wawasan yang tidak berdasarkan contoh karya yang ada. Tetapi siswa dapat membuat suatu inovasi baru dan peran tenaga pengajar akan membantu dalam pemahaman mengenai robotika dan mempraktikkan robotika tersebut (Sri, 2010). Dengan demikian, dalam implementasinya siswa menjadi aktor utama dalam mengoperasikan dan merakit robotika sehingga siswa dapat meningkatkan keterampilan dalam berpikir untuk terus kreatif. Kegiatan ini dilakukan untuk membuat robot berdasarkan ide dan pemahaman sehingga mereka dapat membuat suatu karya ini diikuti dengan bermain agar mereka tidak tertekan jika terdapat suatu permasalahan dalam merakit robot tersebut. Pada SD Negeri Karangrejo 2 ini siswa dituntut untuk membuat sebuah karya robot line follower 
sehingga siswa dapat mengenal, mengembangkan dan membangun kepercayaan diri dalam membuat suatu karya.

\section{KESIMPULAN DAN SARAN}

Pada kegiatan robotika yang dilakukan bagi siswa usia SD memiliki pengaruh terhadap keterampilan berpikir secara kreatif. Hal ini dapat dilihat dari kegiatan robotika yang tidak hanya dilakukan sebagai pembuatan suatu karya dalam bidang robotika. Tetapi kegiatan robotika ini memiliki pengaruh terhadap potensi diri yang ada di siswa tersebut seperti dalam pengembangan diri untuk dapat memecahkan permasalahan dalam merakit suatu robot. Hal ini akan berpengaruh terhadap kreativitas dan kemandirian bagi siswa tersebut untuk terus dapat melakukan inovasi untuk dapat menciptakan suatu karya sehingga kepribadian siswa tersebut akan berkembang dan meningkatkan rasa kepercayaan diri dalam mengekspresikan ide dan hasil pemikiran mereka. Dengan demikian, kegiatan robotika ini dapat mempengaruhi thinking skill bagi siswa usia SD. Mereka dituntut untuk dapat memecahkan dan mencari jalan keluar atas permasalahan yang terjadi dan dalam membuat suatu karya pun mereka dituntut untuk dapat berinovasi untuk menciptakan sesuatu karya yang baru berdasarkan ide dan hasil pemikiran mereka.

\section{UCAPAN TERIMA KASIH}

Tanpa mengurangi rasa syukur kepada Allah SWT, artikel ini saya persembahkan kepada:

1.Untuk keluargaku, Suami, Putra saya, Papa, Mama dan kakak, terima kasih atas segala kasih sayang, doa sehingga dilancarkan dalam segala hal.

2.Dosen pembimbing Bapak DR. Abdul Muhid, terima kasih atas segala bantuannya, nasehat, sehingga dilancarkan dalam segala hal

3.Untuk para masyarakat agar dapat mengasah pendidikan putra dan putrinya dengan kegiatan Robotika.

\section{DAFTAR RUJUKAN}

Aceng Sambas, Mujiarto, Gugun Gundar, Shofiatul Ula. (2019). "Pelatihan Robotika Berbasis Android Untuk Menumbuhkan Inovasi dan Kreativitas di SMP 11 Bandung" Jurnal Pengabdian Masyarakat, Vol. 2, No. 1, 8-12, doi” 10.31604/jpm.v2il.8-12

Ahmad Susanti. (2011). Perkembangan Anak Usia Dini. Jakarta: Kencana

Ahmad Susanto. (2013). Teori Belajar Dan Pembelajaran Di Sekolah Dasar. Jakarta: Kencana Prenada Media Group 
Amal Abdussalam. (2005). Mengembangkan Kreativitas Anak. Jakarta: Pustaka Al-Kautsar.

Ani Rizqi Imroatul Kusni. (2019). "Peran Guru dalam Meningkatkan Kreativitas Siswa Melalui Ekstrakurikuler Robotik di MI Muhammadiyah Plus Suwaru Bandung Tulungagung." Skripsi dalam Institut Agama Islam Negeri (IAIN) Tulungagung.

Ario Wiratmoko. (2012). "Pengaruh Kegiatan Ekstrakurikuler Robotika Terhdap Kecerdasan Emosial Siswa Di Smk Negeri 3 Yogyakarta.” Skripsi, Universitas Negeri Yogyakarta

Baradista Dimas L, Darwin Rio Budi S, dan Priyono. (2016). "Pengembangan Robot Edukasi Sebagai Media Pembelajaran Ekstrakurikuler Robotika Studi Kasus SMP Al muslim Bekasi." Jurnal Pendidikan Teknik dan Vokasional. Vol. 2, No. 2, 32-41, doi: doi.org/10.21009/JPTV.2.2.4

Endra Pitowarno. (2006). ROBOTIKA: Desain, Kontrol dan Kecerdasan Buatan. Yogyakarta: Andi Offset

Harry Andheska. (2016). "Membangun Kreativitas Siswa dalam Pembelajaran Menulis dengan Memanfaatkan Media Pembelajaran Inovatif." Bahastra, Vol. XXXVI, No. 1, doi: 10.26555/bahastra.v36i1.5058

Hotman P. (2012). Siregar, Mekanika Robot Berkaki. Yogyakarta: Graha Ilmu.

Ika Widiastuti, Syamsul Arifin, Beni Widiawan. (2016). "Peningkatan Kreativitas Siswa SD Negeri Karangrejo 2 Melalui Ekstrakurikuler Robotika." Seminar Hasil Penelitian dan Pengabdian Masyarakat Dana BOPTN. ISBN: 978-602-14917-3-7

Indira Sunito, dkk. (2013). Metaphorming Beberapa Strategi Berpikir Kreatif. Jakarta: Indeks. Kasmadi (2013). Membangun Soft Skills Anak-Anak Hebat. Bandung: Alfabeta.

Kementerian Pendidikan dan Kebudayaan Republik Indonesia. (2014). Peraturan Menteri Pendidikan dan Kebudayaan Republik Indonesia No. 62 Tahun 2014. Diakses pada 18 Mei 2020, https://bsnp-indonesia.org/id/wp-content/uploads/2009/06/PermendikbudNomor-64-tahun-2013-ttg-SI.pdf

Mohammaad Asrori. (2011). Psikologi Pembelajaran. Bandung: Wacana Prima

Nashori, Fuad dan Rachmy Diana Mucharam. (2002). Mengembangkan Kreativitas dalam Perspektif Psikologi Islam. Yogyakarta: Menara Kudus.

Robert Coughlin. (1994). Penguatan Operasional dan Rangkaian Terpadu Linier. Jakarta: Erlangga.

Robert L Solo. (2007). Psikologi Kognitif, Eds Delapan. Jakarta: Erlangga.

Sri Saparahayuningsih. (2010). "Peningkatan Kecerdasan dan Kreativitas Siswa”. Jurnal Kependidikan Dasar, Vol. 1, No. 1, https://journal.unnes.ac.id/nju/index.php/kreatif/article/download/1665/1872

Sutan Surya. (2012). Tes Bakat \& Kepribadian. Yogyakarta: Citra Aji Parama.

Ulfa Khusnatul Hidayah. (2018). "Pengembangan Kreativitas Siswa Melalui Ekstrakurikuler Robotika (Studi Kasus di MIN 4 Madiun). Skripsi dalam Institut Agama Islam Negeri Ponorogo.

Undang-undang No. 20 Tahun 2003 Tentang Sistem Pendidikan Nasional

Utami Munandar. (2012). Pengembangan Kreativitas Anak Berbakat. Jakarta: Rineka Cipta 
Vollstedt, Ann-Marie, Robinson, Michael, \& Wang, Eric. (2007). Using Robotics to Enhance Science, Technology, Engineering, and Mathematics Curricula. Nevada: University of Nevada. Proceedings of the 2007 American Society for Engineering Education Pacific Southwest Annual Conference

Winarno dan Deni Arifianto. (2011). Bikin Robot itu Gampang. Jakarta: Kawan Pustaka.

Yeni Rachmawati dan Euis Kurniati. (2012). Strategi Pengembangan Kreativitas Pada Anak Usia Taman Kanak-kanak. Jakarta: Kencana

Yeni Rachmawati. (2010). Strategi Pengembangan Kreativitas pada Anak Usia Taman KanakKanak. Jakarta: Kencana.

Yuliani Nuraini dan Bambang Sujiono. (2010). Bermain Kreatif Berbasis Kecerdasan Jamak. Jakarta: Indeks. 